\title{
Library as a Social Place
}

\section{Wan Hashimah Wan Ismail, Lily Ting Shu Chi}

\author{
Faculty of Built Environment, \\ Universiti Teknologi Malaysia, \\ 81310 Johor Bahru, Johor, Malaysia \\ wan7137shima@gmail.com, lilyting93@hotmail.com
}

\begin{abstract}
This paper clarifies on the condition of the public libraries, focusing on the one in Alor Gajah town. The objectives were to search the reasons for the lack of visitors to the library, the perspectives of the locals and library users, as well as the means to assimilate their viewpoints into a new approach in designing a library. The discussions in the findings include the preference of the locals, the location and the users of the public library. The strategies suggested comprise the role of the library to be redefined as a social interactive space for the community.
\end{abstract}

Keywords: public library; social; Interactive space; community

eISSN 2514-7528 @ 2019. The Authors. Published for AMER ABRA cE-Bs by e-International Publishing House, Ltd., UK. This is an open-access article under the CC BY-NC-ND license (http:///creativecommons.org/licenses/by$n c-n d / 4.0 /$ ). Peer-review under responsibility of AMER (Association of Malaysian Environment-Behaviour Researchers), ABRA (Association of Behavioural Researchers on Asians) and CE-Bs (Centre for EnvironmentBehaviour Studies), Faculty of Architecture, Planning \& Surveying, Universiti Teknologi MARA, Malaysia. https://doi.org/10.21834/jabs.v4i12.329 


\subsection{Introduction}

Most of the people recognize the library as a place for borrowing books but not a community place for social activities. Visits to several public libraries in the country showed the lack of visitors and underutilized. The scholars consider the public library as the least preferable place to go for leisure time and the orthodox mindset of the public contributes to the underutilization of the library. Some scholars consider that the library is always set in a serious and restrained environment with total silence and the visitors have to automatically behave silently inside the library. Apart from that, the poor library space planning leads to the creation of unfriendly and uninviting spaces. In some libraries, the public is not given a clear and direct access to the important spaces, causing them to have less interest to revisit the place.

Many people nowadays do not think of the library as the first place to look for the information as they can get it from the online resources anywhere. On the other hand, people are not aware of the services in relation to the online resources are also provided in the libraries (Connaway, 2015). Both situations are turning the people away to a more relaxed and laid back environment instead of spending their time in the library. The biggest challenge of the public library is to attract the younger generations who tend to stay at home and choose virtual repositories rather than physical libraries.

The scholars suggest that it is crucial to integrate the users' perspectives into the building design as the sense of attachment of the user to a place can greatly affect their attitude towards the spaces perceived. Thus, the study seeks to understand the locals' perceptions and preference of place in Alor Gajah in order to formulate the relevant library design strategies. The study aims to investigate the new approaches in the design of a public library and to upgrade it as a social interactive space. The first objective was to clarify the reasons why the public library in Alor Gajah was underutilized. Secondly, to investigate the kind of activities preferred by the locals in the town. Thirdly, to investigate the new approaches to designing a public library that suits the locals in the town and elsewhere.

\subsection{Literature Review}

\subsection{Alor Gajah town and built structures}

Alor Gajah is both a town and a district seat in Melaka, Malaysia. It is located on the north part of Melaka state. The name of the town was derived from the Malay words for the routes (alor) and elephants (gajah). The legend of the place stated that the early settlement was part of the frequent route of the wild elephants. The settlement was established at the end of the 19th century. The growth of the settlement includes the building of three rows of the old shophouses in the early 20th century, lining the primary streets of the town. In 1978 the local authority was established to handle Alor Gajah district and 32 sub-districts around it. As the small town grew, a few public buildings were built by the authority between the years 1970 to 1980 . These new buildings include a municipal building that houses the local authority, post office, offices, schools, and library. In 2003 Alor Gajah was upgraded to a township. 
Alor Gajah district and the sub-districts have a population of 188,666 inhabitants, as noted by the Department of Statistics, Malaysia (2015). The town itself has a population of 26,267 inhabitants within an area of 660 square kilometers. The majority $(66 \%)$ of the inhabitants were in the age group of 15 to 64 years. According to the age distribution, the inhabitants at the age of 10 to 19 years old topped (23\%) the list. Over the years, many institutions were built within the district and the sub-districts of Alor Gajah. The buildings include schools and 12 higher learning institutions. The students consisted of the locals as well as from elsewhere in Malaysia and overseas.

\subsection{Library}

A public library was one of the buildings built in the town by the local government. Generally, a library is always referred to as a building or a room keeping various kinds of reading materials, films and recorded music for people to read, borrow or refer to. The libraries can be in different sizes, ranging from a few shelves of books to several millions of items. There are different types of libraries in Malaysia. Each library has its own specific roles and governance body. The different types of libraries in Malaysia are listed in Table 1.

Table 1: Type of libraries in Malaysia

\begin{tabular}{|l|l|l|}
\hline \multicolumn{1}{|c|}{ TYPE OF LIBRARIES } & \multicolumn{1}{|c|}{ CATEGORIES } & ADMINISTRATIVE POWER \\
\hline National Libraries & \multicolumn{1}{|c|}{-} & Federal government \\
\hline Public Libraries & $\begin{array}{l}\text {-State libraries } \\
\text {-Community libraries }\end{array}$ & $\begin{array}{l}\text { State government / Local } \\
\text { authority }\end{array}$ \\
\hline Special Libraries & $\begin{array}{l}\text {-Government libraries } \\
\text {-Corporate libraries } \\
\text {-NGO's libraries }\end{array}$ & $\begin{array}{l}\text { Government agency / Private } \\
\text { Agency / NGO }\end{array}$ \\
\hline Academic Libraries & $\begin{array}{l}\text {-Institute of higher learning } \\
\text { libraries }\end{array}$ & $\begin{array}{l}\text { Ministry of Higher Education / } \\
\text { Ministry of Education (MOE) / } \\
\text { Government ministries }\end{array}$ \\
\hline School Libraries & $\begin{array}{l}\text { Ministry of Education / } \\
\text { Private agency }\end{array}$ \\
\hline
\end{tabular}

(Source: Author, 2017)

A library that possesses five basic characteristics can be defined as a public library (Rubin, 2016). The characteristics include it is supported by the local government, aims to serve the public interest, opened to all, the services provided are free of charge and the public is not forced to use the facilities. Unlike the other types of libraries which have their own specific serving groups, public library serves all the members in the community regardless of their age, gender, race, religion and educational background (Gill et al., 2001). A public library is said to be a neutral ground as it is not predominated by any social groups (Sloan, 2013). It is a place for everyone especially for those with lacking reading facilities at home. It provides a non-judgmental space for literacy, learning, and sharing.

\subsection{Public Libraries in Malaysia}

Libraries in Malaysia have long existed even before being taken over by the western powers. According to Lim (1986), the libraries in the olden days were very small in scale and were 
used to facilitate particular religious studies. After World War II, the idea of public libraries was introduced in new villages during the period of communist activity in Malaysia. These public libraries were aimed to improve the social, educational and cultural standards of the villages in hopes that it would work against communism at that time.

The number of public libraries is growing every year and the coverage even extends to the remote areas of the nation (Raslin, 2012). The intention was to ensure that every citizen has equal literacy opportunities. However, the reading habits of Malaysians significantly affect the sustainability of public libraries. A recent study reveals that the books read by Malaysians in a year have increased from 2 books to 8-12 books. However, the statistics shown are still far behind developed countries whose citizens read 20 books a year (Nawe, 2016). Pandian (2004) argues that students in Malaysia only read to pass exams and to complete their academic tasks.

A study on the National Library showed that it was poorly designed and maintained (Chu, 2013). The important library spaces were located at the back of the building while a big portion of space near the main entrance was used for exhibition purposes. Certain levels of the library building were rented out to third parties unrelated to the library, such as management companies and a law firm. The unwelcoming library access and blurred focus of the library function were not representative of a 'national' library (Ong, 2013).

\subsection{Social meeting place}

The library is always set on a serious and restrained environment. The visitors are expected to behave silently when using the library (Aarts \& Dijksterhuis, 2003). In contrast, several scholars relate to the library as the third place and not a quiet place. The concept of the third place promoted by Oldenburg (Butler \& Diaz, 2016) refers to places where people occupy time between homes ('first' place) and work ('second' place). Both Oldenburg (1989) and Codispoti (2007) for instance, relate to the library and some other public buildings with the concept of third place. The reason is due to the provision for the interaction and socialization among the visitors (Codispoti, 2007). The idea can be applied in the urban development (Hui Lin et al., 2015). The library can become a common meeting place for the community without any segregation according to social group or class (Oldenburg, 1989).

Some researchers claim that the physical library turns to be an important asset to a society as it establishes connections between the people and the needs of the community (Garmer, 2014). The library is said to be an open public space where the community is given free access to the resources and services provided and hence gathering the community together and interact with one another (Johnson, 2008). Therefore, a library can be a crucial social place to bring the people together and build up the community cohesion.

According to the research done by Aabo, Audunson, and Varheim (2010), the results revealed that the people are using the library as a social meeting place to suit the personal needs and intentions. This can be categorized into 6 distinct functions; library as a place for both formal meetings (meta-meetings) and the virtual meetings, as a public sphere for all, as a square to meet people from different walks of life and as an active place for different social groups. The suggested different functions of a library are summarized as in Figure 1. 


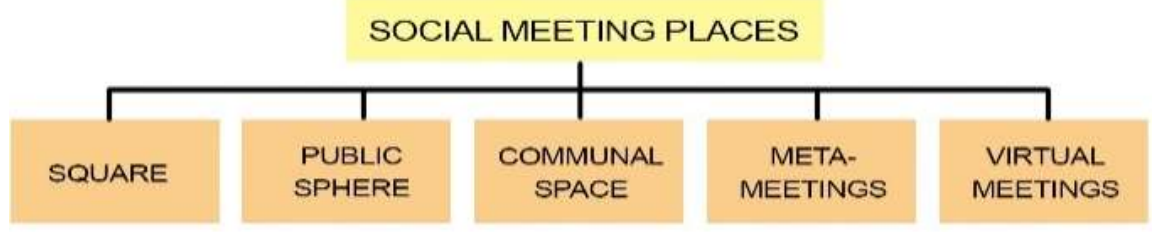

Fig 1: The library as social meeting places

(Source: Author, 2017)

Moreover, the study shows that the lower income groups tend to use the library as a social meeting space more often than the higher income groups. The most popular visitors were the students who were engaged in educational projects. According to Cabello \& Butler (2017), some changes were made to the existing libraries to transform them into social places for the public. The changes include the creating of a comfortable, relaxed ambiance with attractive design as well as providing the related amenities. The main intention was to attract more people to visit the library. These libraries started to become less restrictive by bringing in the café or even nap rooms for the people to have a quick rest between their study sessions. In some of the public libraries over the globe, they focus on a wider range of populations with specific social needs and serving the locals. Some libraries, for instance, provide free programs for the immigrants by giving assistance and support to help them to adapt to the new places.

However, some people including the local authorities do not perceive the public libraries as a social interactive space for the community. Budgets for libraries are cut and some of the libraries are even co-locating other services which are not related to the library itself. Such a situation is actually happening in the National Library of Malaysia. Certain levels of the National Library are rented out to the third parties including a law firm and a management company (Chu, 2013). The blurring function of the library and the poor maintenance of the library could be some of the reasons why the general public turns away from it. The library is merely recognized as a place for borrowing books and not a place for social interaction.

\subsection{Library design}

Shakeel (2015) suggests that carefully planned library spaces are able to attract the attention of the users into the library. This suggestion was supported by Jong (2016), noting that the users' perceptions of the library environment can significantly affect the spatial design of a library. The design of the public library plays a crucial role in serving the community from all walks of life. A good public library design is able to fulfill the needs of its community through a comprehensive space planning process. According to the Whole Building Design Guide (2017), the design process of a library should be started off with a projection on the community's needs for 20 years. The purpose is to enable the designers to determine the required spaces to accommodate the changing needs of the users. According to Sloan (2013), public libraries are playing multiple roles in the community. Apart from serving the information in physical and digital formats, it is also significantly serving as a place for the 
community to socialize and interact. Hence, the public-orientated design solutions should be prioritized while designing a public library.

According to Whole Building Design Guide (2017), the design and planning of the library spaces are affected by the greater service population in the community. For instance, if the community consists of a large population of elderly people, the public library, therefore, should include the design criteria that fulfill their needs such as easy access and provision of lighting, signage, and furniture that suits the senior citizens.

Thus, the public library has distinct functions compared to the other library types. However, according to Sullivian (2017), the architects or the designers of the libraries easily overlook these differences by proposing similar designs to all categories of users. Inappropriate planning and unsuitable approaches during the design stage may lead to underutilization of the building. Sullivian (2017) suggests that the library spaces should include public-orientated spaces, such as media lab, café, and bookstore.

Based on the research done by Lin, Pang, and Luyt (2015), an inviting library space includes 3 main roles; a social place, a study place and leisure place (Figure 2). The quality of the library spaces is essential to enhance the social interaction activities. The cafe can be included as one of the mandatory spaces to the library design (Cho \& Deng, 2016). Library café is a trend among university students for both formal and informal learning activities. It also provides a space for social engagement where the people gather and converse comfortably. As for the study place, Montgomery (2014) notes that even though people opt to work alone for most of the time, they prefer a working environment, surrounded by other people. Obviously, people get motivated and inspired by seeing the others working.

As for now, the emergence of computer technology is changing the way the public library functions. The internal planning and design need to accommodate the multimedia or even gaming rooms for the users. Designers of the modern public libraries today are adopting flexible library design that is compatible with the changing technology in term of the electrical and wiring needs. Barclay (2017) refutes that people still need a physical library as the internet world could not offer a real physical space that people can actually gather to share their thoughts and idea verbally with one another.

\subsection{Methodology}

The data concerning the town, the locals, public libraries, focusing on the one in Alor Gajah, was collected through various means. The methodology of the research includes literature review, observation, questionnaire and semi-structured interview of the locals. All the data collected were then analyzed. Only then, it was possible to make appropriate proposals and suggestions to improve the existing public library at Alor Gajah or other libraries elsewhere. Ten people were involved in collecting and processing the data. The team included the author, co-author and nine architectural students from Universiti Teknologi Malaysia.

\subsection{Literature Review}

The study on the general public library design was performed before focusing on the public library at Alor Gajah town. The literature review was done by reading through various 
resources such as books, journal papers, articles, old photographs, and videotapes. The first aspect was on the library design, to have a comprehensive understanding of the public library and to gain knowledge on the new approaches in design. The other aspect of the literature review was on the town. Apart from the sources of information already mentioned, some documents on the town were also collected from the local authority. The primary concern was to have an overview of the background of the locals, the history of the town and the built structures.

\subsection{Observations}

The observations on the town were conducted in three aspects during the day and at night in a period of 2 weeks. The first aspect was the facilities available around the town, particularly close to the public library. Secondly, the observation was done on the activities and movement of the locals. The spontaneous behaviors of the people were observed and notes were taken by the data collectors stationed at several locations in the town. Thirdly, the observation at the public library was done by the author and the co-author. The concern was on the location, architecture, environment, facilities, circulation and the users of the public library.

\subsection{Questionnaires}

The quantitative data of the study was obtained through 2 sets of questionnaires. The first set of the questionnaire was on 40 locals concerning their preferences in the town. The second set was done on 47 respondents focusing on the library. The structured questionnaires with closed-ended and open-ended questions format were distributed among the 40 locals and 47 library users. The questionnaires consisted of dichotomous questions and scaled questions. The choices of the respondents were limited to a set of options provided.

\subsection{Semi-structured Interview}

The interview was conducted in a semi-structured manner whereby some questions were prepared. The questions were subjected to be changed in term of sequences and wordings in order to create a more comfortable and casual atmosphere. This allows the interviewees to express their opinions in their own terms. The entire interview session was recorded so that the outcome could be referred back to the analysis.

\subsection{Results \& Discussion}

\subsection{Urban issues}

Alor Gajah town has a central open place (Dataran Keris) (Figure 6a). In the past, there was a football field at the center that had enlivened the town. Apart from the football games, major events were also held there and it was where the locals spent their leisure time. However, the football field was replaced by a sculpture, a stage, a museum, a children playground, shops, public toilets, and some green spaces. The area and even the museum 
seem to be empty most of the time. The findings through the questionnaires suggested that the locals considered the place to be unattractive and unfriendly for spending their leisure time.

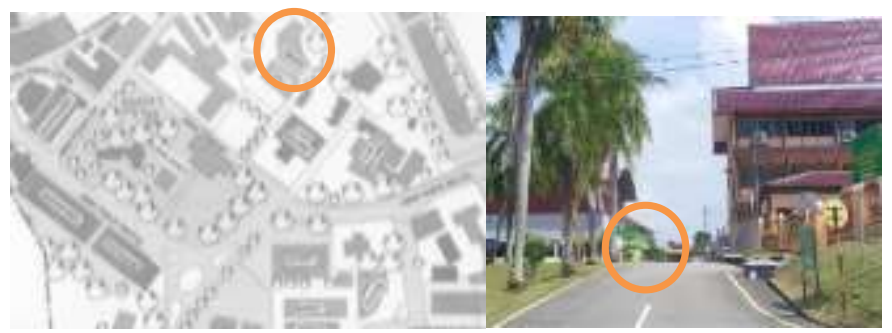

Fig. 5: (a) Plan of Alor Gajah town; (b) View of the public library from the central open place (Source: Author, 2017)

The central open place formed the core of the town and the local library was placed only about 100 meters away. However, the library building was blocked by the multi-purpose hall (Figures $5 \mathrm{a}$ and $5 \mathrm{~b}$ ). In the past, two roads that surround the central open place was closed on the weekends and used as an open market with stalls lining up the streets. It was very popular and crowded with shoppers. However, the crowd did not notice or extend their visit to the local library. Even though the library was located at a higher point of the town, the view towards the building from the popular eatery was blocked by the 3-story civic building. From the questionnaire, it was found that many of the locals were not aware of the existence of the library (Figures 6a and $6 \mathrm{~b}$ ) in the town. Furthermore, the porch and entrance of the library was at the back, rather than fronting the main route to the building.

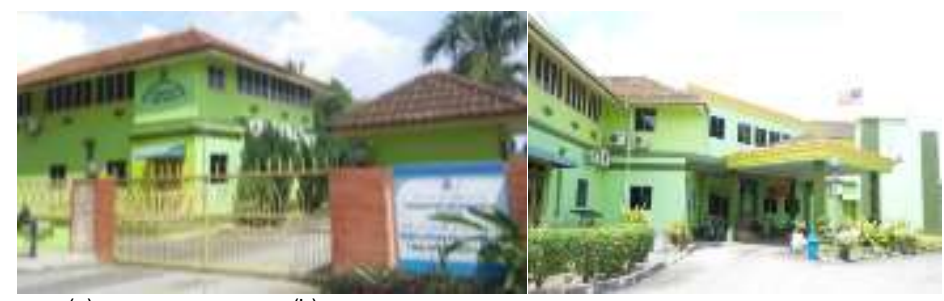

(a)

(b)

Fig. 6. (a) The back of the public library; (b) The front of the public library

(Source: Author, 2017)

\subsection{Architectural issues}

There were both positive and negative findings from the observation of the exterior and interior of the library. The exterior was brightly painted with cheerful colors. The porch and the entrance clearly welcomed the visitors (Fig. 6b). The main spaces provided were children section on the ground floor and the adult section on the upper floor. The other supporting spaces include praying rooms, toilets, storage area and office. The interior was brightly painted and well decorated. It had sufficient daylight and artificial lighting. The interior of the 
library indicates that it was a very neat, clean and clearly organized space. There was a clear arrangement of the bookshelves. However, there were also redundant spaces.

Through observation, it was very quiet inside the library due to the lack of visitors or background music. During the observation period, less than ten people used the library daily. It was found that the public library was primarily used by the school children after the school hours. Only at times that there were elders reading newspapers in the lobby of the library. No working adults were found to go to the library throughout the study period. The library also lacked technology integrated facilities since only one computer was provided.

\subsection{Social issues}

Based on the data collected from 40 locals, the majority of them (65.1\%) preferred to stay at home after work or school, instead of going out. More than half $(58 \%)$ of those who liked to go out, preferred to be in indoor spaces rather than outdoor places (Figure 3). However, even though the respondents claim that they more prefer to stay at home, yet the analysis of data obtained reveals that majority of the respondents (42.5\%) would spend 2 days a week outing with friends or families (Figure 4). The result of the data analysis also suggested that $60 \%$ of respondents rated the eateries as the most preferable place to go to Alor Gajah town. This explains why the town main eatery (Medan Selera Pasar Menggong) was always crowded with people, both during weekdays and weekends.

The findings through the questionnaires were supported by the outcome of the observation on the daily activities and movement of the locals. Based on the observations conducted from day to night, it was found that the locals preferred to stay at home after work. All the shops in the town were closed after 8 p.m. even during weekends. The business hours of the shops (restaurants, grocery stores, and family businesses) at the town were relatively short compared to those at Melaka city, located $25 \mathrm{~km}$ away.

During the weekdays, the businesses in the town were running as usual yet most the shops were opened late in the morning while some even opened their stores afternoon time. During daytime, the crowd could be spotted in a few places including banks, post office, bus terminal wet market, and eateries. The school areas would be congested only in the early morning and at the noon time as parents would park their vehicles nearby to drop and pick up their children. During the weekends, most of the shops were closed except for the wet market and eateries. The parking lots next to the main eatery would turn into the night market on Saturday night and morning market on Sunday morning. Other than that time, the town remained quiet and peaceful. The preferences of the locals in the town indirectly explained the unpopularity of the public library. For most of the time, people tend to gather at the foodrelated places, such as food courts, restaurants and markets.

The outcome of the questionnaire on 47 respondents indicated that the main purpose of visiting the library was to borrow library materials $(40.4 \%)$, followed by to meet friends for group study $(38.3 \%)$ and to kill free times $(21.3 \%)$. Thus, the majority of them had purposes other than borrowing books. About a third (36.2\%) of the respondents did not like the formal environment of the library. The formality, in this case, means everything needs to be done quietly. One quarter $(25.5 \%)$ of them considered the location of the library to be nonstrategic, detached from the other places for socializing. The rest of the respondents (38.3\%) 
considered being at other places was more favorable than the library.

Browsing through the books in the library, it was found that many of the references were outdated. This could be another reason why the library was underutilized. As mentioned in the literature review, there were schools and 12 higher learning institutions in the district and sub-districts of Alor Gajah. It was expected that each school and institution has its own library as indicated in Table 1. The public library will be more favorable to students if it can offer references beyond what was available in the library of their schools or institutions.

The findings from the questionnaire on 40 respondents of the locals supported the findings mentioned earlier. None of them mentioned spending their leisure time at the local library. According to the locals, the town lack entertainment places. Hence during weekends, they would take the public bus from the local bus terminal or drive to Melaka city to enjoy the facilities such as gym, hypermarket and shopping complexes. Through the interview of a library staff, it was found that the library also lacked publicity and community engagement programs.

\subsection{Conclusion}

In conclusion, the study on the public library in Alor Gajah town clarified the underutilization of the place. The lack of visitors was unpredictable despite the close proximity to schools and 12 higher learning institutions within the district and the sub-districts of Alor Gajah, as mentioned in the literature review. It was also mentioned that the majority $(66 \%)$ of the inhabitants were in the age group of 15 to 64 years. At this age, one would expect them to be enthusiastic about seeking knowledge at the library. The outcome of the study showed otherwise.

The study suggested several factors that contributed to the public library being underutilized. The first was regarding its hidden location in the town. Secondly, it was not well connected to the active areas of the prospective users, such as the eating court, the shops and the central open place of the town. The third factor was the quietness and formality of the interior that was not favorable to some users. The fourth factor was the outdated references found in the library.

Reviewing the public library design of the town, a large area of the library spaces were utilized as study areas only. The space planning of a public library in the town could be based on the perceptions of the locals. As noted by Jong (2016) it is crucial to integrate the users' perspectives into the building design as the sense of attachment of the user to a place can greatly affect their attitude towards the spaces perceived. Thus, the aspects to be considered include the integration of identified local elements into the public library design and the inclusion of mandatory public library spaces namely a social place, entertainment place and study place. It was found that the preferable social place for the locals evolved around the food, for eating and meeting friends from the same neighborhood. Thus, the library could be integrated with an eating place, a discussion corner, and other social places, apart from the pile of books as references.

The local elements vary from one place to another and it should be able to reflect the local identity as well as the perspectives and perceptions of the general public. The local 
elements to be integrated can be the art, beliefs, dwellings or other local culture which is able to reflect the feelings of appropriateness and rightness to the local context. Some of these elements can be integrated into the design of a public library.

\section{Acknowledgement}

This study was made possible by the continuous support from Universiti Teknologi Malaysia.

\section{References}

Aabo, S., Audunson, R., \& Varheim, A. (2010). How do Public Libraries function as Meeting Places? Library \& Information Science Research, 32(1), 16-26.

Aarts, U. \& Dijksterhuis, A. (2003). The Silence of the Library: Environment, Situational Norm, and Social Behavior. Journal of Personality and Social Psychology, 84(1), 18-28.

Barclay, D. (2017). Space and Social Worth of Public Libraries. Public Library Quarterly. 36(4), pp. 267-273.

Butler, S. M., \& Diaz, C. (2016) 'Third Places' as Community Builders. https://www.brookings.edu/blog/upfront/2016/09/14/third-places-as-community-builders/

Cabello, M., \& Butler, S. M. (2017). How Public Libraries Help Build Healthy Communities.

https://www.brookings.edu/blog/up-front/2017/03/30/how-public-libraries-help-build-healthy-communities/

Cho, A., \& Deng, T. (2016). Library Café as a Place for Collaborative Learning - Measuring the Educational, Social and Recreational Functions of University Library Cafes. https://www.slideshare.net/allancho/library-cafe-as-a-placefor-collaborative-learning-a-comparative-study-between-the-university-of-tsukuba-university-of-hong-kong-and-theuniversity-of-british-columbia

Chu, M. M. (2013). 13 Signs The Condition of Our National Library is a Reflection of Malaysia's Governance. http://says.com/my/news/worry-observations-of-the-malaysia-national-library-according-to-ong-kian-ming

Codispoti, M. (2007). The Library as Third Place in Academe: Fulfilling a Need for Community in the Digital Age. Popular Culture \& American Culture Association Annual National Conference.

Connaway, L. S. (2015). The Library in the Life of the User: Engaging with People Where They Live and Learn. Ohio: OCLC Research.

Garmer, A. K. (2014). Rising to the Challenge: Re-Envisioning Public Libraries. Washington: The Aspen Institute.

Gill, P. et. al. (2001). The Public Library Service: IFLA/UNESCO guidelines for development. Ohio: IFLA Publications.

Hui Lin, Natalie Pang, \& Brendan Luyt. (2015). Is the Library a Third Place for Young People? Journal of Librarianship and information Science, Vol 47, Issue 2, 145-155.

Johnson, C. A. (2008). Social Capital and Public Library: An Investigation of the Relationship? Proceedings of the American Society for Information Science and Technology, 44(1).

Jong, A. K. (2016). Dimensions of User Perception of Academic Library as Place. The Journals of Academic Librarianship. 42(2016), 509-514. 
Wan Ismail, W.H., \& Chi, L.T.S. / Journal of ASIAN Behavioural Studies (jABs), 4(12) Jan / Apr 2019 (p.48-59)

Lim, H. T. (1986). Public Library Services in Malaysia: An Analysis. Emerald Insight: Library Review, 35(1), 5-12.

Lin, H., Pang, N., \& Luyt, B. (2015). Is the Library a Third Place for Young People? Journal of Librarianship and Information Science, 47(2), 145-155.

Montgomery, S. (2014). Library Space Assessment: User Learning Behavior in the Library. Journal of Academic Librarianshi, 40(1), 70-75.

Nawe, B. L. (2016). The Reading Habits among Library Users in Rural and Urban Areas of Sarawak, Malaysia. Sarawak State Library, Malaysia. The Asian Conference on Society, Education \& Technology 2016 Official Conference Proceedings. https://papers.iafor.org/wp-content/uploads/papers/acset2016/ACSET2016_33259.pdf Oldenburg, R. (1989). The Great Good Place. New York: Marlowe \& Company.

Ong, K. M. (2013). A Recent Visit to Our National Library: Some Worrying Observations. https://www.facebook.com/notes/ong-kian-ming/a-recent-visit-to-our-national-library-some-worryingobservations/46690736003099

Pandian, A. (2004). A Study on Readership Behaviour Among Multi-Ethnic, Multilingual Malaysian Students. The International Journal of Learning: Annual Review, 8(1).

Raslin, A. B. (2012). Library Services and Trend in Malaysia. Perpustakaan Negara Malaysia.

Rubin, R. E. (2016). Foundations of Library and Information Science. Chicago: ALA Neal Schuman, Fourth Edition.

Shakeel, A. K. (2015). User's Perception of Services Quality of the Central Public Library Bahawalpur. Library Philosphy and Practice (e-journal).

Sloan, E. (2013). Library as Place in Communities: A Literature Review.

https://theidaholibrarian.wordpress.com/2013/11/17/library-as-place-in-communities-a-literature-review

Sullivian, M. (2017). Designing for Community: 10 Essential Library Spaces.

http://www.demcointeriors.com/blog/designing-community-10-essential-library-spaces/

Whole Building Design Guide. (2017). http://www.wbdg.org/building-types/libraries/public library 